\title{
2. The Worlding of the Asian Modern
}

\author{
John Clark
}

This paper reconsiders the historical depth and global range of art works and practices that we might call the 'Asian Modern'. ${ }^{1}$ It will not rehearse the copious arguments for, ${ }^{2}$ and some against, ${ }^{3}$ the notion of a modernity in Asian art emerging parallel to and, at the same time, in concert with, modernity in Euramerica. Suffice it to reiterate that the Asian Modern is an hermeneutic construct for interpreting multiple art discourses; an empirical field for understanding and ordering the minutiae of data about art practice and interpretation; and, a periodisation that can be culturally and historically denoted in a particular set of geographically defined entities, which became the modern state system in Asia from the onset of late Euramerican colonialism in the eighteenth century until the end of colonial rule in the mid-twentieth century. To facilitate discussion, there is no harm in putting indicative dates on this period and location; i.e., from the Battle of Plassey in 1757 in India, up to the end of the Third Vietnam War in 1976. This may be taken notionally to slightly extend up to the fall of Soviet communism in 1989/1990, which was roughly contemporary with the tensions that reached brief but bloody resolution in China in the 1989 massacre in Beijing's Tian'anmen Square.

In practice in art and in the still largely absent discourse of a worlded art history that takes account of Asia, the Asian Modern denotes a broad period with slightly different empirical artistic delineations to the political. It varies from a threshold marked by, say, the foundation of Damián Domingo's art school in Manila in 1821; by the first exhibition of a major Asian artist, Raden Saleh, at a European salon, in Amsterdam in 1834, or by his exhibition in the French salon in 1847; or, by the first counter-colonial appropriation of academy style for a history painting in Saleh's 1857 The Arrest of Prince Diponegoro. The overall period of the Asian Modern, which offers much to be subdivided by further

\footnotetext{
1 This paper adapts sections and ideas from papers in which I have previously explored similar themes: 'The Changing Nature of Paris as a World Art Capital for Chinese (and Some other Asian) Artists', in Artistes chinois à Paris, ed. \& cur. Eric Lefebvre (Paris: Musée Cernuschi, 2011); 'The Southeast Asian Modern: Three Artists', in Modern and Contemporary Southeast Asian Art: An Anthology, ed. Nora Taylor (Ithaca: Cornell University Press, 2011), 15-32; 'The Asian Modern, Approaches in Defining the Contemporary in Asian Art', Journal of the History of Modern Art 30 (December 2011): 145-66.

2 In my book Modern Asian Art (Sydney: Craftsman House \& Honolulu: University of Hawai'i, Press, 1998), I argue for a constructed 'Asian Modernity', not that of Euramerica. See also, Jonathan Hay, 'Double Modernity, Para Modernity', in Antimonies of Art and Culture: Modernity, Postmodernity, Contemporaneity, eds Terry Smith, Okwui Enwezor, Nancy Condee (Durham, N.C.: Duke University Press, 2008), 113-32.

3 The Marxist determinism of Fredric Jameson leads him to consign all the difficult cases of pre-modernity to a reactionary past defined against Euramerica. See, Fredric Jameson, A Singular Modernity: Essay on the Ontology of the Present (London: Verso, 2002), 53.
} 
micro analyses, lasts up to the first exhibition of Chinese artists on any scale at the Venice Biennale in 1993, which can be seen as a globalised stage and not merely one covered by an immanent Euramerican hegemony. It is capped, symbolically, by the first acquisition of a work from a modern Asian artist by the canon-keeper at the Euramerican art centre: the 1997 acquisition by the Museum of Modern Art, New York, of Zhang Peili's video Eating [or Ingesting].

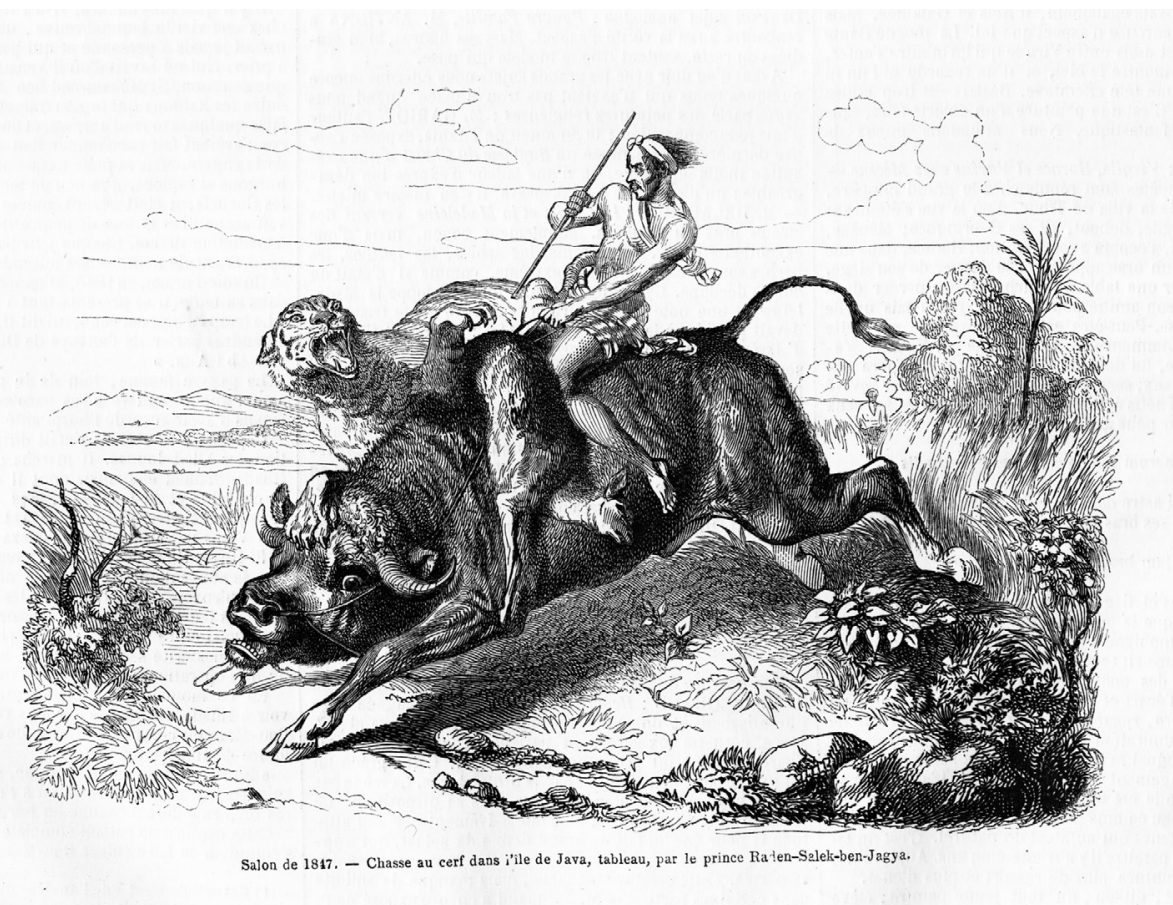

\section{Raden Saleh, Hunt on Buffalo Salon de 1847; wood engraving from L'Illustration vol. IX, no 0217, Samedi, 24 Avril 1847, p. 117.}

Photograph from the journal

Speaking periodically, one may of course take the Asian Modern forward, or back, from the mid-1990s, but most observers would consider that the empirical nature of art practice, its pragmatic interlinking and its hermeneutic positioning changed after that point, in Euramerica, worldwide, and in Asia. The mid-1990s saw the advent of the 'postmodern' - some would say 'postpostmodern' - 'postcolonial', 'global' or 'transnational' as bounding concepts for art practice and interpretation. These are articulated top-down to a set of upwardly and laterally articulated local discourses, many of which exist inside the global, but to which some local discourses also pay scant attention. One indeed sees the 'worlding' of phenomena - the application of interpretive frames to art discourses that are visible in a global perspective across cultural 
and temporal zones - that have been occluded, by Euramerican domination, as derivative or different from those in Euramerica. This occlusion did not mean these discourses, which include parallel or alternative modernities made possible by that worlding, had not been there already, however difficult to view they might have been from a Euramerican position.

'Worlding', from the outset, meant making local interpretive frames visible in a global perspective across cultural and temporal zones because, from the early nineteenth century, there was the potential for local discourses to penetrate the non-local. In a sense, this is counterintuitive to a simple view of colonial processes as the imposition of a hegemony, rather than the collaboration with it. Such access had, at least theoretically, to include kinds of articulation of the local into the non-local and vice versa. 'Worlding' is a notion which implies a coherence other than that provided by internal discourses: it posits an outside, and this depends on how the nature and extent of the outside were reciprocally conceived. The problem for later nationalist, anti-colonial conceptions of art discourses was the level at which the inclusive was to be conceived. Or, what is that which includes, inclusive of? If it includes the pre-colonial it is, in this perspective, a domination of the culturally other by the colonial hegemony. If it excludes the pre-colonial, it is also a hegemony of exclusion where assimilation of art discourses is to the colonial order, and only on its terms.

'Worlding' posits a spatial and temporal discontinuity with innerness, but it is, in the colonial and nationalist anti-colonial conceptions, mobilised by outerness. 'Worlding' is marked, sometimes temporarily, by the period when a discourse is supposed to have overcome its inwardness or closure, or it is spatially designated as in distant, regional, provincial styles within an art culture. ${ }^{4}$ These relations depend on types of inheritance of the pre-modern, or transitional modern, and their relation to later formation of domestic discourses.

'Worlding' means that these continua are given an externally constructed presence in the formulation and attribution of authority to art discourses now, whatever they carry forward internally or intrinsically. External, objectivist interpretations, as much as internal subjectivist ones, are equally and necessarily ideological.

Modern Asian art discourses have arisen in conditions where there have been internal or endogenous forces at play, with external or exogenous demands and provision of models. It is important now, in postcolonial times, to reconsider more carefully the ways of conceiving the distinction between exogenous and

4 On closure and openness, see my essay, 'Open and Closed Discourses of Modernity in Asian Art', [1991] in Modernity in Asian Art, ed. John Clark (Sydney: Wild Peony, 1993); reprinted in Contemporary Art in Asia: A Critical Reader, eds Melissa Chiu \& Benjamin Genocchio (Cambridge, Mass.: MIT Press, 2011), $27-45$. 
endogenous art discourses since the resulting works have become the originary works for long-term and, in most cases, almost wholly endogenous genealogies of the modern.

The task of understanding the Asian Modern is first of all to know what the artists did to map their work and times, and then to compare them. The Asian Modern had its inception in the early to mid-nineteenth century and I have divided it by marking five generational artistic cohorts, since the empirical materials fall into five rough chronological groupings with corresponding patterns of artistic practice. One of the features of artistic generational cohorts is that they fall into very rough correspondences between artists active at the same time, but may be in different stylistic trajectories. This loose empirical correlation also produces a sense of chronological divisions which are more like domains or clouds of influence and interference rather than rigid analytical categories or temporal boxes. Based on empirical research and comparative historical categorisation, for me these cohorts are:

- I Transitions to Modernity, 1850s-1890s

- II Academy Realism, Salon Art and the National, 1880s-1910s

- III Early Modernism, 1920s-1930s

- IV Abstractionism and Conceptualism, 1940s-1960s

- V The Contemporary, 1980s to the Present.

Cohorts have the feature of viewing the 'worlding' of the Asian Modern as both an inward or exogenous process and, at the same time, an outward and endogenous one. They take art history away from seeing change as dependent on external or hegemony-down origination, and as a more complex intermediate zone that is in part isolated from the forces of modernity they also manifest. Despite its apparently broad temporal and geographical scale, my project is small and initial in this direction. This essay represents the summary of work in progress that I have undertaken up to 2010, and its conclusions are therefore tentative.

\section{Types of Siting of Artists in Art Discourses}

It pays to consider in detail where artists are sited, and the range of situations for artists, both domestically and internationally. What does the domestic, interior, or endogenous siting of artists in art discourses mean? There were not one, but multiple, types of these discourses, which later critics, historians and nationalist aestheticians called 'traditional' in apposition, and often opposition, to the 'modern'.

In Type One, artists who never go abroad have contact with foreign discourses via exemplars that are locally designated as such by a patron. 
We may take as an example the Siamese muralist Khrua In Khong, who was active in the 1850s and 1860s, but of whom little is directly known. Much may, however, also be deduced from works by him, or attributed to him. It is important that he is nameable and known, since even if he was the subordinate painter of a king, his reputation exceeded his social subordination. Indeed, there are anecdotes that indicate Khrua In Khong was assured of his own métier, and this changed self-consciousness of the artist as a professional is certainly one index of modernity in art. $^{5}$

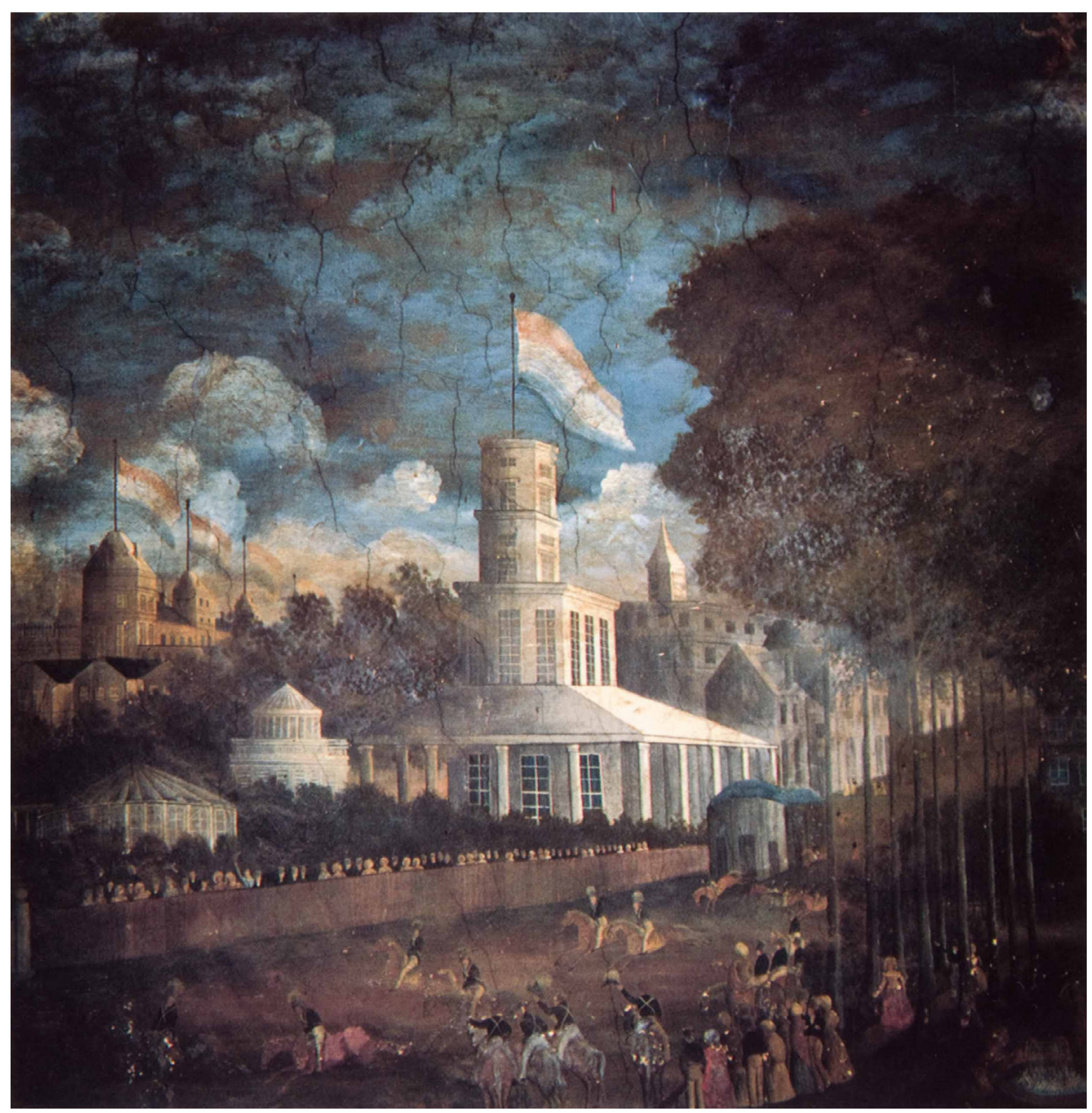

Khrua In Khong, Horsemen training c. 1850s; Wat Borom Niwat, Bangkok.

Photograph from Wiyada Thongmitr, Khrua In Khong's Westernized School of Thai Painting, Thai Painting Series No. 1, Bangkok: Muang Boran, 1979

5 See Wiyada Thongmitr, Khrua In Khong's Westernized School of Thai Painting (Bangkok: Thai Cultural Data Centre, 1979), 110; quoting Saan Somdet (Princes' Correspondence) III \& XII (Bangkok: Khurusapha, 1962). 
The art world he inhabited was one hierarchically governed by royal, aristocratic and sometimes merchant patronage for mural decorative schemes in temples and palaces. ${ }^{6}$ Khrua In Khong was aware of a rich, iconographically and stylistically variegated temple painting discourse, and also of the reputation of previous masters. His work's claim to mastery over a new pictorial discourse thereby relativised the customary works of the past, which would be reassessed by his own work, and is thus pre-eminently a modern assertion. ${ }^{7}$ It happens that the mastery claimed by his works rests in an external, or exogenous, visual discourse. This discourse represents the pressure to absorb Euramerican visual styles that existed under the various threats of cultural domination, and opportunities to counter-appropriate the art styles and forms received from nineteenth century colonialism. Since these were found widely across SouthEast Asian art, Khrua In Khong is an interesting example of an artist emerging from a hitherto craftsman substratum. ${ }^{8}$

As an artist he was embedded as a monk-painter in the religious mission to produce paintings as narrative or allegorical expostulation and, in a society where incorporation of new visual discourses was only possible if they were ideologically sanctioned by an abbot or an aristocrat; in his case this would have certainly been directly ordered by the king. ${ }^{9}$ Yet, his work is largely the application of drawing techniques, pictorial composition, spatial construction and painting technique, which given the apparent explicitness of his use of Euramerican cityscapes for Jataka scenes, was derived from Euramerican art. These influences can be dated, with some precision, from reviewing the 1855 list of images presented to the king by the US envoy Townsend Harris. ${ }^{10}$ But it is almost certain, given the early life of Khrua In Khong's patron, King Mongkut, from 1836-1850 as a monk at Wat Bowon Niwet, a major teaching monastery where the king came to know the French Abbé Pallegoix, ${ }^{11}$ Khrua In Khong moved in circles that had access to late eighteenth and early nineteenth century illustrated books from Europe, particularly France.

\footnotetext{
6 See Saran Thongpan, 'Chiwit thang sangkhom khong chang nay sangkhom thaay phaak klang samay ratanakhosin kon P.S. 2448' ('The social life of craftsmen in Central Thailand society of the Ratanakhosin era before 1905') (master's thesis, Thammasat University, P.S. 2534 (1991)); Akin Rabibhandana, The Organization of Thai Society in the Early Bangkok Period, 1782-1873 (Bangkok: Wisdom of the Land Foundation \& Thai Association of Qualitative Researchers, 1996).

7 See also, John Listopad, 'The Process of Change in Thai Mural Painting: Khrua In Khong and the Murals in the Ubosot of Wat Somanasa Vihāra' (master's thesis, University of Utah, 1984).

8 See Thongpan, 'Chiwit thang sangkhom khong chang nay sangkhom thaay phaak klang samay ratanakosin kon P.S. $2448^{\prime}$.

9 In a January 2008 conversation with me, the specialist on Thai mural painting, Professor Santi Lekhsukhum, averred that the use of elements from Western pictorial discourses by Khrua In Khong was inconceivable without the direct intervention of King Mongkut, Rama IV, given the social subordination of painters at that time.

10 Townsend Harris's list of American printed material among gifts to King Mongkut, Rama IV, is found in Abbot Low Moffat, Mongkut, King of Siam (Ithaca: Cornell University Press, 1961).

11 Jean-Baptiste Pallegoix (1805-1862) was the author of the dictionary Sappha phačhana phāsā Thai = Dictionarium linguce Thai: sive Siamensis interpretatione Latina, Gallica et Anglica (Paris, 1854), and also of
} 
The habitual Euramerican interpretive position of assessing the inadequate copy', which so denigrates endogenous discourse and how it nests the exogenous, does not mean that Khrua In Khong would not have benefited from knowing more accurately how to generate his own images within the Euramerican tendencies that he chose. Indeed, instrumental drawing of a medical kind was certainly known in his lifetime. We can assume it was a Thai artist who illustrated the midwifery manual produced in 1843 by the American medical missionary Dr Bradley, for use by royal midwives. We may also speculate that technical drawing was known to the architectural technicians who created a kind of neo-Georgian style for certain buildings ordered by King Mongkut in the 1850s and 1860s. King Mongkut had sent a diplomatic mission to London and Paris in 1857.

Khrua In Khong would probably have known something of this in his larger perspective constructions, but even more so in his technique for getting chiaroscuro effects. These clearly fascinated him. He tried to go against the zonal red grounds on white distempered walls that was practised by previous Thai muralists in the 1830s. These grounds created a vibrating and complementary contrast effect on green or mixed hues that were used elsewhere in the quite unconnected Venetian oil painting. Khrua In Khong seems to have deliberately chosen dark and, in some cases, very dark grounds against which to set bright contrasts through the addition of white.

In Type Two, the artist never goes abroad, but has contact with foreign art discourses that are currently in favour among resident expatriate foreigners. This artist is found frequently among Chinese treaty port painters in service to make largely topographical paintings for foreign merchants from the 1780s to the 1860s, or in Yokohama in the 1860s and early 1870s. The type may be thought to characterise many craftsmen who were active across a variety of visual discourses, including those used in printing industries, at many entrepôts.

In Type Three, the artist never goes abroad and has contact with foreign discourses via educational institutions and often resident foreign teachers. In the Philippines, Simon Flores (1839-1902) typifies that type of artist who did not travel abroad and yet whose discourse has a nested exogenous component. To understand this we need to consider the longevity and particular structures of Spanish colonial art in the Philippines.

the Description du Royaume Thai ou Siam (Paris: Mission de Siam, 1854), which was widely used by Sir John Bowring in his The Kingdom and People of Siam (1857), and translated by Walter E.J. Tips, as Description of the Thai Kingdom or Siam: Thailand under King Mongkut(Bangkok: White Lotus Press, 2000). 


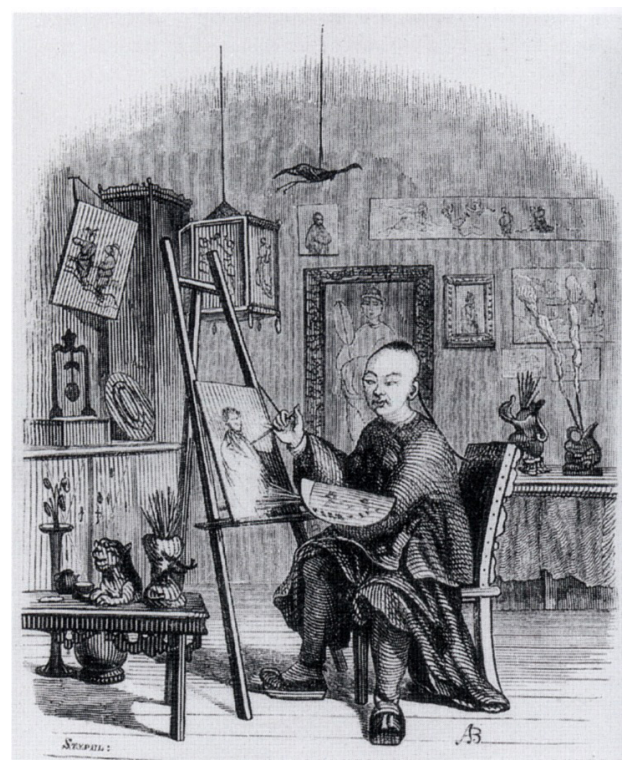

\section{August Borget, 'Lamqua in his Canton studio', La Chine Ouverte 1845.}

Photograph from the journal

An art school was founded in the Philippines by local worthies and functioned from 1821-1834 under Domingo (ca. 1790-1833/1834), and an art academy was authorised in 1845, regulated in 1848 and opened from 1850-1898. It was followed by the School of Fine Arts of the University of the Philippines from 1908 to the present day, whose first director, Rafael Enríquez, was significantly a Spaniard born in the Philippines and a former student of the Manila Academy.

The Chinese relationship with Philippines' art is deep and longstanding, particularly via paintings and glass paintings done in Chinese treaty ports and which, from these ports, spread to the Philippines, ${ }^{12}$ and via tipos del pais, sets of images of typical occupations having reached Manila from Canton in the 1790s, which were a staple element in the production of Domingo and some of his students from the late 1820 s. $^{13}$

There is very little early Philippine history painting. That which exists seems largely to have been produced by late nineteenth century academy-trained artists.

12 On glass painting in Asia, see Seiichi Sasaki et al., 'Yooroppa Yûsaiga no Nihon dotchaku katei no kenkyû-Doro-e, Garasu-e kenkyû' ('The settling-down process of European coloured painting in Japanresearch on gouache, glass painting'), Tama Bijutsu Daigaku Zairyôgaku Kenkyûshitsu Kiyô 1 (1976), 2 (1978), 3 (1982), 4 (1985).

13 On tipos del pais, see Francisco de Santos Moro, La Vida en papel de arroz (Madrid: Museo Nacional de Antropología, 2007). On Damián Domingo's works, see Jose-Maria Cariño \& Sonia Pinto Ner, Álbum Islas Filipinas 1663-1888 (Manila: Ars Mundi, Philippinae, 2004); Nick Joaquin \& Luciano P.R. Santiago, The World of Damian Domingo (Metropolitan Museum of Manila, 1990); Stephen Ongpin, Filipino Master: 
There are records of The Conquest of Batanes having been painted by an anonymous naturales and adorning the Palacio Real in Intramuros, but this was destroyed by earthquake in 1863. The only other example, which fortunately survives, is an important 1821 regional painting by Esteban Villanueva (17981878) - a regional painter about whom little is known - that is held in Vigan in Ilocos Norte and which records an uprising and its relentless suppression. ${ }^{14}$

Flores' Woman with a Religious Image (undated, but possibly the late 1870s to mid-1880s), is close to the Spanish notion of portrait realism, in the manner of Velasquez and Murillo, possibly via copies which had been ordered from Spain for the Manila Academy from the 1850s-1860s. ${ }^{15}$ It is likely that Flores, therefore, had several styles, one being the realism in the manner sanctioned by the Spanish academy and, the other, a kind of informal genre painting for intimate themes. This can be regarded as an articulation of a distance between an elaborately decorated surface, putatively that required by the patron, and the raw incarnation of the human body which carried it. To date, interpretation has been restricted by there being no surviving image or illustration of Flores's 1875/1876 La Orquesta del Pueblo (Musicians of the Town), which was exhibited by Spain at the Centennial Exhibition in Philadelphia in 1876, where it is said to have won a silver medal. ${ }^{16}$

Type Four artists only go abroad to sojourn, and take up temporary residence in a foreign country, such as Yoshimatsu Goseda (Period I), Juan Luna (Period II), Amrita Sher-Gil (Period III), Abdul Latif Mohidin (Period IV), and Zhang Peili (Period V).

In Type Five, temporary sojourners become long-term residents by dint of circumstance, such as Pan Yuliang (Period III) in Paris, who wanted to return to China later in life, but was prevented from doing so by the Cultural Revolution.

\footnotetext{
14 See Patrick D. Flores, Painting History: Revisions in Philippine Colonial Art (Manila: National Commission for Culture and the Arts, 1998), 288-93; Santiago Albano Pilar, 'The Basi Warriors', Archipelago (May 1976). Pilar's essay was seen by Roberto Feleo and became the inspiration for new works exhibited in 2007 at the National Museum, Manila. Images of the Basi Revolt paintings and Feleo's works can be viewed online: http://hugzone.multiply.com/photos/album/90/BASI_REVOLT_IN_ART.

15 See Flores (Painting History, 247), for a list of these works. There is no surviving evidence that such copies arrived; but, the Dr Eleuterio Pascual collection includes early copies by Juan Luna, executed before he went to Spain in 1876 and which I have seen, of portraits of Phillip IV of Spain after Velasquez (Museo Nacional del Prado P-1185, ca. 1653) and purportedly of Cervantes (but more likely to be Pablo de Vallaldolid, Museo Nacional del Prado p-1198, ca. 1635). See Javier Portús Pérez et al., El retrato español, del Greco a Picasso (Madrid: Museo del Prado, 2004), 117, 226.

16 Some sources have yet to be examined, but the retrospective catalogue (Francis A. Walker, International Exhibition 1876 Reports and Awards Vol VII Group XXVII (Washington: Government Printing Office, 1880)) neither mentions the Philippine exhibits nor illustrates them. It does, however, include an illustration of the general hang in the Spanish section, and lists the Spanish artists, as opposed to those from Cuba, the Philippines and Puerto Rico. Other Philadelphia Centennial Exhibition records to be investigated further indicate the title of a work by Flores, that was exhibited in 1876, to be A Village in the Province of Pampanga.
} 
Contemporary Asian Art and Exhibitions: Connectivities and World-making

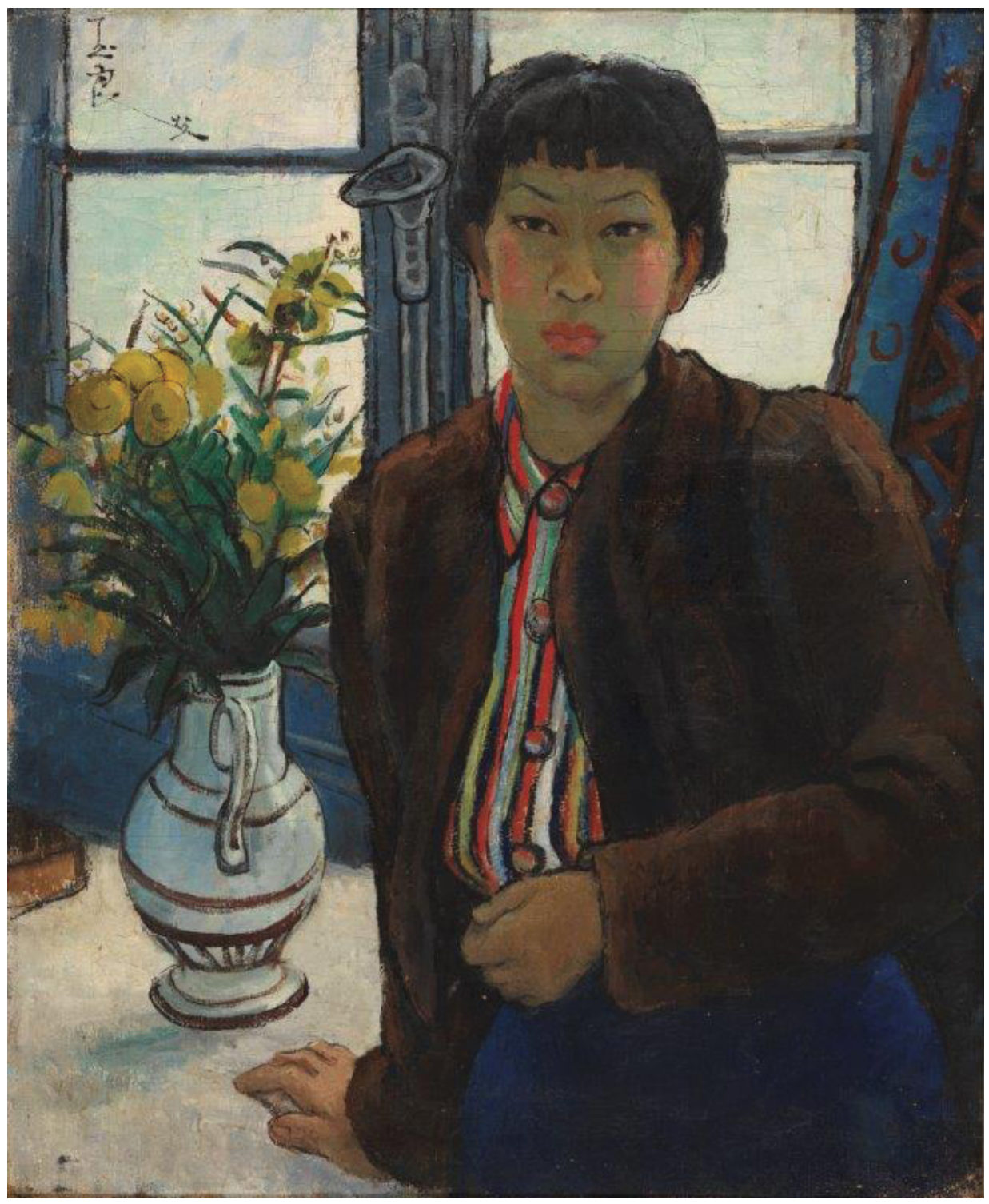

Pan Yuliang, Self-Portrait 1945; oil on canvas; 60 x $73.5 \mathrm{~cm}$.

National Art Museum of China, Beijing; photograph provided by the Museum 
Artists in Type Six engage in intermittent returns to their home countries; that is, they can temporarily return home, but become long-term residents by choice of artistic affiliation. For instance, Zhao Wuji or Yan Peiming in France, who often return to China, but for much of their active life remain resident in one country, such as France, or centre, such as Paris. Some, such as S.H. Raza or Yang Jiechang, become permanent residents and acquire various signs of acculturation: a local spouse, a domicile, a studio, a gallery, a côterie of local or other resident foreigner friends.

Type Seven is usually constituted by artists who have left home for reasons of political or artistic exile; a circumstance that may become one of intermittent return if the situation that forced them to go abroad is resolved, such as Chinese Wang Keping, Ai Weiwei and Huang Rui from The Stars group in 1979-1982.

Type Eight is the site of transhumant cosmopolitans. In a last (but by no means the last) type of siting for an artist, such as Wang Du in France and Paris, or Cai Guo-Qiang in the United States and New York, the artist comes to regard an overseas country or city as a regular port of call. ${ }^{17}$ It becomes a stopping-off point or base for studio and family in a style of living that is between sites and basically globalised, to whose cultural specificities the artist might be relatively unattached. This type is a kind of artistic transhumance, which depends on the quality of local mediation and acceptance, as well as access to art markets or sites of primary cultural appraisal. These do not have to be stationary and are, in the main, not in a given overseas country.

Type Eight is also a kind of siting by a self-awarded prerogative, perhaps like the apanage or prerogative claimed by French aristocrats, where there is a quasifeudal claim to ownership of certain cultural characteristics, which may be manifested materially or virtually in a non-native place. Against the backdrop of the growing economic and cultural importance of China in the world, deterritorialised discourses of 'Chineseness' have become a kind of marker of access (often negotiated with some irony by 'Chinese' artists, especially in France) ${ }_{1}^{18}$ and the national discourse of Chinese art has become, for a few artists, a de-localised globalised discourse of Chineseness. This type is widespread and Indian (M.F. Husain), Thai (Surasi Kusolwong), Indonesian (Heri Dono), and Malaysian (Wong Hoy Cheong) exemplars also exist. Transnational artists claim the prerogative to carry certain cultural characteristics with them, a selfdeclaration of rights, an apanage which frees them to arrogate the expression of

17 Paris pour escale (Paris as port of call) (2000), included Chen Zhen, Huang Yongping, Shen Yuan, Wang Du, Yang Jiechang (curated by Hou Hanru \& Evelyne Jouanno, organised by Musée d'Art Moderne de la Ville de Paris).

18 See Chen Zhen's 'Transexperiences, A Conversation between Chen Zhen and Zhu Xian', Kitakyushu (1998), (reprinted in Chen Zhen: The Discussions, ed. Jerôme Sans (Paris: les presses du réel/ Palais du Tokyo, site de création contemporaine, 2003)). A Chinese translation of this conversation is included in Xu Min ed., Chen Zhen (Changchun: Jilin Meishu Chubanshe, 2006), 73-95. 
culturally specified contents or subjects at a transnational site, such as overseas commercial or biennale exhibitions. Such artists have deployed (and sometimes deliberately traduced) signs of specific cultural derivation. This discourse does not have to be sited in the claimed culture of origin, such as 'China', or in just one localised and culturally specific site of reception 'outside China'.

If, in this last type, artists have carried the notion of their access to culturally defined experiences or forms outside their culture, what has been that outside for modern Asian artists, and has it changed in nature over time?

\section{Transitions to Modernity, 1850s-1890s: Appropriation and Counter- Appropriation [I]}

The styles and practices of art under what I will call transitional or protomodernity were much more than mere counter-appropriations adopted under the constraints of colonialism or neocolonialism.

One can begin briefly with a progenitor who can be recognised as an international cosmopolitan, the Indonesian artist, Raden Saleh (ca. 1811-1880), who worked with natural history, familial and individual portraits, and rarely with historical subjects. If he had not spent so much time abroad in the Netherlands, Saxony and France, it would be easier to locate Saleh within the general context of modern Asian discourses. The discrimination of modern South-East Asian art discourses occurred later, and on multiple grounds, but Saleh stands at the head of a long line of Asian artists whose relationship with exogenous discourses - the function of which was to relativise endogenous discourses - started with deep, and colonially constructed, contact with European art centres and dominant art styles. ${ }^{19}$

Sir Thomas Raffles, British colonial administrator, noted that, despite there being no traces of an extensive pictorial discourse, the Javanese could be well trained and he mentions 2,000 natural history drawings he selected to take home, but which were lost to fire in $1824 .{ }^{20}$ Javanese and Java-based Chinese artists did

19 For Raden Saleh in general, see the works of Werner Kraus: 'Raden Saleh's Interpretation of The Arrest of Diponegoro: An Example of Indonesian "Proto-nationalist” Modernism', Archipel 69 (2005): 259-94 (also published in Eye of the Beholder, eds John Clark, Maurizio Pelleggi \& T.K. Sabapathy (Sydney: Wild Peony, 2006), 29-55; and, his catalogue of the Saleh exhibition in Jakarta in 2012, Raden Saleh: The Beginnings of Modern Indonesian Painting, eds Werner Kraus, Irina Vogelsang; trans Chris Cave, Werner Kraus (Jakarta: Goethe-Institut Indonesien, 2012). See also work by Marie-Odette Scalliet: 'Raden Saleh et les Hollandais: artiste protégé ou otage politique', Archipel 69 (2005): 151-258 (includes list of paintings done in Holland 1831-1839); and, Antoine Payen, peintre des Indes orientales: Vie et écrits d'un artiste due XIXe siècle (1792-1853) (Leiden: Research School CNWS, 1995).

20 Cited in Anthony Forge, 'Raffles and Daniell: Making the Image Fit', in Recovering the Orient: Artists, Scholars, Appropriations, eds Andrew Gerstle \& Anthony Milner (Chur: Harwood Academic Publishers, 1994), 112, citing from Memoir of the Life and Public Services of Sir Thomas Stamford Raffles, by his Widow, vol. 2 (London, 1830), 329-30. 
some of the original drawings which illustrated the three major English texts of the 1810s and 1820s about Java. ${ }^{21}$ Raffles also brought with him an Anglo-Indian artist whose hand, or whose atelier, must have been responsible for a screen depicting Javanese noble attendants; the screen, later in a Danish collection and now in the Rijksmuseum, Amsterdam, bears some similarity with earlier North Indian, so-called 'Company' paintings. ${ }^{22}$

Unlike the hybrid application of a 'Company Painting' manner to the subject of Javanese nobles, it is clear from surviving drawings that, for Saleh, his visual discourse was, from the outset, European. He received early training in drawing, during 1819-1820, from the then Dutch, later Belgian, artist Antoine Payen. ${ }^{23}$ He must also have been present when Payen did some of his in situ oil sketches of natural scenes, which he later worked up in Europe into formal compositions. In fact, Payen's early oil sketches should be seen as the originator of landscape painting in Java ${ }^{24}$ and, by implication, of the whole later tendency, which was disparagingly called Mooi Indie (Pretty Indies).

Saleh is the first artist of Asian origin to have received training in European studios and to have exhibited at a European salon. ${ }^{25}$ From 1845 to 1848 he was largely in Paris, where he was visited in his studio by a linguist of Malay, Auguste Dozon, who was accompanied by his friend the, then unknown, poet Charles Baudelaire. This was probably the first encounter of a major figure in the European artistic avant-garde with an Asian painter. Saleh exhibited Chasse au Tigre at the Salon in 1846, a work in the manner of Horace Vernet (whom he had met), and which was subsequently purchased by Louis-Philippe, who was known as 'King of the French'. His work in the Salon of 1847, Chasse au cerf dans l'isle de Java, was noticed by Théophile Gautier, and an image was reproduced in L'Illustration.

\footnotetext{
21 Forge indicates that the illustrations are in three texts: William Marsden's History of Sumatra (1811); those depicted in Raffles's 1811-1816 History of Java, and subsequent variations; and, those by Adi Warna, who illustrated 11 of 34 plates in John Crawfurd's History of the Indian Archipelago (1820). See also, Annabel Teh Gallup, Early Views of Indonesia: Drawings from the British Library (Honolulu: University of Hawai'i Press, 1995).

22 For an illustration, see John Clark, 'Presenting the Self', Ars Orientalis 43 (December, 2013): 67-81.

23 On Payen, see Scalliet, Antoine Payen. I am also grateful for the opportunity to see and photograph Payen's oil sketches, which were done in situ in Java, at the Ethnology Museum in Leiden.

24 See Tony Day, “"Landscape” in Early Java', in Gerstle \& Milner, 198.

25 Earlier, see David Clarke, 'Chitqua's English Adventure: An Eighteenth Century Source for the Study of China Coast Pidgin and Early Chinese Use of English', Hong Kong Journal of Applied Linguistics 10, no. 1 (2005): 49.
} 


\section{Academy Realism, Salon Art and the National, 1880s-1910s: [II]}

Modern Asian art discourses have arisen in conditions where there have been internal or endogenous forces at play, with external or exogenous demands and provision of models. It is important now, in postcolonial times, to reconsider more carefully the ways of conceiving the distinction between exogenous and endogenous art discourses since the resulting works have become the originary works for long-term and, in most cases, almost wholly endogenous genealogies of the modern. The scope of this essay does not allow me to pursue all of these issues for the artists of Period II. It is important to point out, however, that in the era of formation of 'national' art discourses - which in Australia, India, and Japan corresponds to the decades from 1880 to 1914, with China following similar patterns under different historical constraints in the 1920s and 1930swhat could be seen as an appropriation or assimilation of Euramerican art styles by successful artists from outside, is also to be seen as a counter-appropriation of those styles and practices. This can be regarded as having been given its space - its room for domestic siting - by the continuation of customary aesthetic modes which are non-Euramerican.

Many more Japanese artists in Period II, among whom was Hosui Yamamoto, were to come to Paris in 1878-1888. Soon after his arrival in Paris he provided illustrations for the Poèmes de la Libellule by Judith Gautier and Kinmochi Saionji. After his return to Japan he was known for a theatrical visualisation of Japanese myths. An artist of lesser social origin from the marginal samurai and Meiji craftsman class, Goseda, lived and worked in Paris from 1881-1886. He was the first Japanese artist to exhibit at a French salon in 1881 and 1883.

But, among the grandest Asian artists was Juan Luna from the Philippines, a member of the illustrado class, who was later intimately involved in the liberation war against Spain. He was in Europe from 1877-1894, and in Paris, 1885-1893, where he changed from the academy grand manner, which had won him the gold medal at Madrid in 1884, to a lighter, impressionist and more spontaneous style. Even though Luna was relatively well-off, and married into a wealthy family, he had attended the 1882 funeral of the Italian general and politician Giuseppe Garibaldi, who may have provided Luna with a model of a nationalist hero, and some of Luna's Parisian works were depictions of the working-class life of Italian labourers in the district of Paris where he lived.

Among remarkable similarities, several Australians, who did not identify themselves as 'Asians', were Tom Roberts and Margaret Preston. Roberts was in Europe for several periods (1881-1885, 1903-1919, 1921-1923), and in Paris 
in 1883. On his return he directed light-toned pleinairisme towards allegories of heroic figures of settlers who embody the values of developing the bush or harvesting agricultural plenty.

Roberts came to Paris just before the arrival of Seiki Kuroda, who settled there from 1884-1893. Soon after returning to Japan, Kuroda executed a celebrated and, in nationalist terms, equally allegorical portrait of an apprentice geisha. In significant institutional reinforcement of the pedagogy of French art, which Kuroda learnt in France, he took over the private art school founded by Yamamoto, and went on to become the first professor of oil painting at the Tokyo School of Fine Arts in 1896.

Preston, also from Australia, was in Europe 1904-1906 and 1912-1918, and in Paris from 1905-1906 and 1912-1913, the same period during which a second cohort of Japanese artists was studying in France. Preston first encountered Japanese prints at the Musée Guimet in Paris and redeployed their design conventions in the 1920s for scenes of Sydney Harbour.

It is perhaps too soon to clearly see how these Australian artists, who have hitherto been conventionally viewed as working in extensions of Euramerican discourses, in fact were trying to develop their own national art in ways not so dissimilar to their Asian counterparts. The difference was that the Australians found their situation within a 'tradition' thought to be European, and the Japanese thought the contents of their 'traditions' uniquely their own. Different contexts of colonial domination between a neo-colonial Japan in the 1880s and 1890s and a set of colonies in Australia dependent on a colonial metropolis, did not allow both of them to be seen in the same frame. In fact the artistic careers and travels of these Japanese and Australian artists frequently crossed and sometimes intersected. It is only the use of later mid-twentieth century nationalist blinkers which now prevents us seeing them in the same field of view.

\section{Early Modernism, 1920s-1930s: The Formalisation of Internality and Externality (Endogeny and Exogeny), Movement and Stability, Localism and Cosmopolitanism [III]}

Whether artists moved or stayed at home, the notional stability and motility of modern Asian artists and artworks seems to be a grounding feature of their existence, one that has sometimes been occluded by later nationalist ideologies. But, these were emplaced in a set of relations between domestic and overseas art centres, which made it no longer feasible to see these relations as merely those of colonial or later neo-colonial following and transfer. 
Indeed the nature of art centres is so various, and changed so completely in Paris, for example, between the 1880s to 1910 s and the inter-world war years. Similarly, changes in the nature of another international art capital, New York, may be observed between the 1960s, when it was a place of training and exhibition for artists from all over Asia, to the 1990s, when it had become a discretionary port of call for artists, rather like Paris had become by the 1970s.

How did the status of Paris as a world art capital for Chinese change between the two world wars? Post-World War I, there was a regular flow of Chinese artists to Paris and France, but clearly not as many as from Japan.

Lin Fengmian was in France from 1918-1923, studying in Dijon and then in Paris at École Nationale Supérieure des Beaux Arts (ENSBA) and the studio of Fernand Cormon, followed by a period in Berlin from 1923. He had significant exhibition activity in the first exhibition of Chinese contemporary art in Europe, Exposition chinoise d'art ancien et moderne, ${ }^{26}$ which he organised at Strasbourg in 1924, as well as a personal exhibition at the Salon d'Automne in 1924 and at the Exposition internationale des arts décoratifs et industriels modernes à Paris in 1925. But the Chinese contribution to this exhibition did not attract much attention and, certainly, contemporary Chinese art was largely ignored by the French critics. ${ }^{27}$

$\mathrm{Xu}$ Beihong was in Paris from 1919-1927, studying with the conservative Pascal Dagnan-Bouveret at ENSBA. He had an important break in Berlin from 1921-1922 when he studied at the Hochschule für bildende künste with the painter Arthur Kampf, a nationalist who later became a Nazi (1864-1950), the implications of whose histrionic nationalist expression escaped his later followers in China. ${ }^{28}$

Pan Yuliang, one of the few major Chinese women modern artists, studied in Lyon and at ENSBA in Paris from 1921-1928, with an important break in Rome to learn sculpture from 1925-1928. She returned to France in 1937, visited the USSR in 1942, and died in Paris in $1977 .^{29}$

\footnotetext{
26 Craig Clunas, 'Chinese Art and Chinese Artists in France, 1924-25', Arts Asiatiques 44 (1989): 101.

27 Ibid., 101.

28 There is absolutely no doubt about Kampf's Nazi sympathies, as for many 'Germanic' academy painters who were absorbed by Nazi culture. See Arthur Kampf, Aus Meinem Leben (Aachen: Verlag Museumsverein, 1950); Ernst Klee, Das Kulturlexikon zum Dritten Reich, Wer war was vor und nach 1945 (Frankfurt: S. Fischer Verlag, 2007), 294. The most recent catalogue is Xu Beihong in Nanyang (Singapore Art Museum, 2008). Xu Beihong's second wife wrote a hagiography of him, see, Liao Jingwen, Xu Beihong, Life of a Master Painter, trans. Zhang Peiji (Beijing: Foreign Languages Press, 1987), which can be useful.

29 Pan Yuliang has a reasonably large bibliography, among which one may mention Huahun: Pan Yuliang (Taibei: Guoli Lishi Bowuguan, 2006), which includes texts by Lu Rongzhi, Jia Defang, Li Fuchang; and Jiang Biwei, Jiang Biwei Huiyilu (Taipei: Huangguan Zazhishe, 1966). There were further Chinese artists in France and an earlier list is found in Li Chu-tsing, 'Paris and the Development of Western Painting in China', which is included in Zhang Yuanjian et al., Zhongguo-Bali, zaoqi liufa huajia huiguzhan zhuanji [1918-1960] (Taipei Fine Arts Museum, 1988), 8, 12.
} 
The changing nature of Paris as a world art capital is also clearly shown in the life experiences of two other visitors to Paris: Tsuguharu Fujita (the later Léonard Foujita), who was in Paris and elsewhere in France in 1913-1929 and 1939-1940; and, the Indian painter Amrita Sher-Gil who was in Paris from 1929-1933.

After World War II, and following a period in New York from 1947-1949, Fujita was in France from 1950-1968. Fujita has always been regarded as the Japanese artist who was most easily assimilated to the French art worlds, having formed friendships with artists such as Picasso, as well as a kind of niche market for his fond blanc Japonais. He married a French woman (like Chang Yu and, indeed, Lin Fengmian married a German woman who died in tragic circumstances before his return to China). ${ }^{30}$ Undoubtedly there is a dimension of Chinese male erotic self-exploration through art, which, like Fujita's, involves exploring the visualisation of the non-Chinese body, but which can now in the main only be explored through the artists' works.

In the case of these artists, separation from home culture also involved a kind of distance from or relativising of the experience of French culture. Why, on Fujita's first return to Japan in 1929, did he not directly return home, but took a long, meandering trip on the way through Argentina and Mexico, made possible by the many artistic and literary contacts that he had formed in Paris? The answer can only be that, for artists like Fujita, however well integrated they became into French artistic life and its sub-society, Paris was as much a site for new kinds of international linkages and sympathies, which would not have been possible in his homeland, but which also were important beyond the site of Paris itself. ${ }^{31}$ Whether there was anything intrinsically Parisian about such possibilities is debatable, as plenty of other cases of such networking and exploration exist in other cities overseas. In other words, one, if not the attraction of Paris was its significance as a site of lateral international connections and not only vertical connections between China or Japan and France: it was these connections which liberated the artist's imaginary from both the constraints of their domestic art world and those of France itself.

Sher-Gil was a young artist when she came to France with her family to study at ENSBA. She can more accurately be characterised as an Hungarian-Indian painter and was in Europe for several periods (1913-1921, 1924, 1929-1934, 1938). She left many photographs of herself and other young artists at ENSBA and it must have been attractive, despite the presence of her elite family and of

\footnotetext{
30 See the entry by Christina Wei-Szu Burke Mathison \& Julia F. Andrews, 'Lin Fengmian', in Encyclopedia of Modern China, ed. David Pong, vol. 2 (Detroit: Gale/Charles Scribner's, 2009). Lin Fengmian's second wife was a French art student, Alice Vattant, who he married in 1925.

31 See Hayashi Yôko, Fujita Tsuguji, sakuhin wo hiraku, tabi, teshigoto, Nihon (Nagoya Daigaku Shuppankai, 2008).
} 
social events organised by them, to have such a wide social network of peers prior to becoming a professional artist. Indeed, Sher-Gil's discovery of, or at least emphasis on, the Indian side of her origins followed her student period in Paris. ${ }^{32}$ The notion of a globalised discourse of 'Indianness' or 'Chineseness', which arises much later in the 1990s, might look for its precursors in the social relations - including sexual self-exploration - of younger artists in a site such as Paris of the 1920s and 1930s. These were people from, or with access to, the wealthy classes in their countries of origin. Their relative privilege can be seen to rehearse the more easily and widely adopted privilege of the students of Period IV, which evolved after World War II, who were able to competitively obtain scholarships to study overseas, such as Abdul Latiff Mohidin or Gulammohammed Sheikh.

\section{Abstractionism \& Conceptualism, 1940s-1960s: Developments under Postcoloniality [IV]}

Did the nature of 'worlding' change after the end of World War II in 1945? Or, did the change occur after the rise of postcolonial states, with their own nationalist cultural agendas and stylistic identifications? Across the cohort of artists throughout Asia in this period, there can be identified a drive for the local and essential, and for a locally conceptualised generality. This went in two directions, sometimes at the same time, sometimes in the work of the same artist.

One direction taken was towards a new narration of 'our people', a subject in storied representation, which was considered to go beyond the constraints of the colonial or external hegemony.

Other attempts were made to concretise 'our national' aesthetic tastes or sensibilities. These are seen clearly in the work of Korean Park Seobo, which switched from a burgeoning figurative narrative, towards an art informel, that was first manifested in the meaningless chaos of the civil war years, in the 1960s. This transformation ceased following the armistice and the resulting hopes for economic development. The shift then went further, however, to a new kind of line writing in pigment, or over differently pigmented grounds. The debt to the late work of the French artist Jean Fautrier was not always acknowledged, given the existing cultural space that sought a national 'Korean'

32 On Sher-Gil see Geeta Kapur, ed., with Vivan Sundaram, Gulammohammed Sheikh, K.G. Subramanyam, Special issue on Amrita Sher-Gil, Marg 25, no. 2 (1972); Yashodhara Dalmia, Amrita Sher-Gil: A Life (New Delhi: Viking/Penguin, 2006); Vivan Sundaram, Amrita Sher-Gil: An Indian Artist Family of the Twentieth Century (New Delhi: Photoink \& Munich: Schirmer/Mosel, 2007). 
aesthetic. If abstraction and conceptualism carried the possibility for this kind of essentialisation of national aesthetic values, they also carried the perils of repetitive factory-like production of a formal stereotype and, later, of elegant, but obvious, redeployments of form types, which could claim national affiliation.

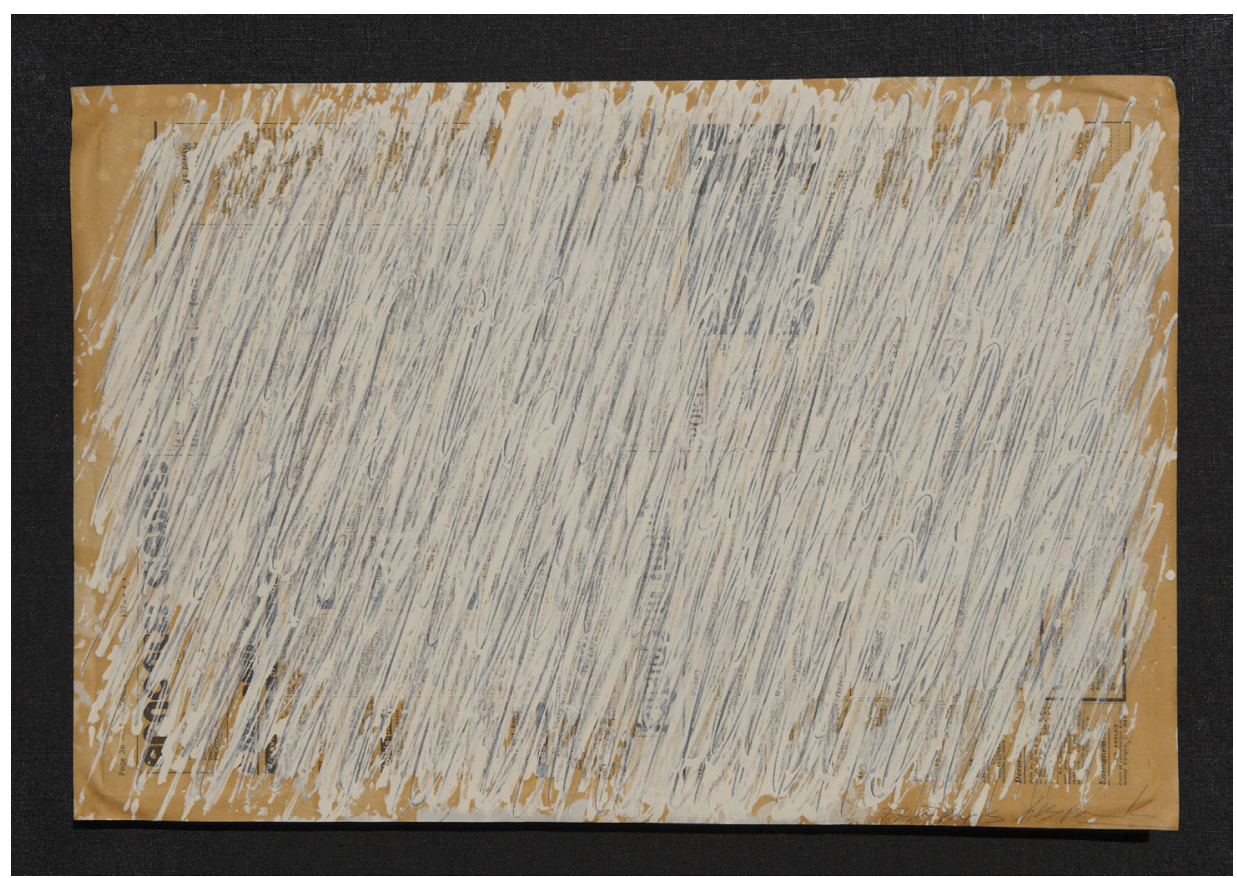

Park Seobo, Écriture no. 45-77 1977; pencil and oil on Le Monde newspaper; $33.5 \mathrm{~cm} \times 50 \mathrm{~cm}$.

Collection of the artist, Seoul; photograph provided by the artist

\section{The Contemporary, 1980s to the Present: Locality and Contemporaneity, the Global Transnational Emerges [V]}

The ability of local discourses to rediscover their own 'tradition' or 'national subjects' and wrap them in approved narratives, combined with the changing nature of exogenous art centres through their pluralisation and volatile shifting through the multiple temporary centres of the biennales of the 1990s, has meant that exogenous art centres can no longer be opposed, tritely, as representative of 'neo-colonialist' hegemony. Endogeneity in local art discourses, which we now associate with particular Asian nations, also shifted in that the eclecticism that 
is one feature of the postmodernity found in international and transnational discourses was a freedom hitherto claimed by local discourses in their nesting of the exogenous. It is now no longer a preserve that has been taken away from them; such eclecticism is now only definable against transnational conceptions of the postmodern.

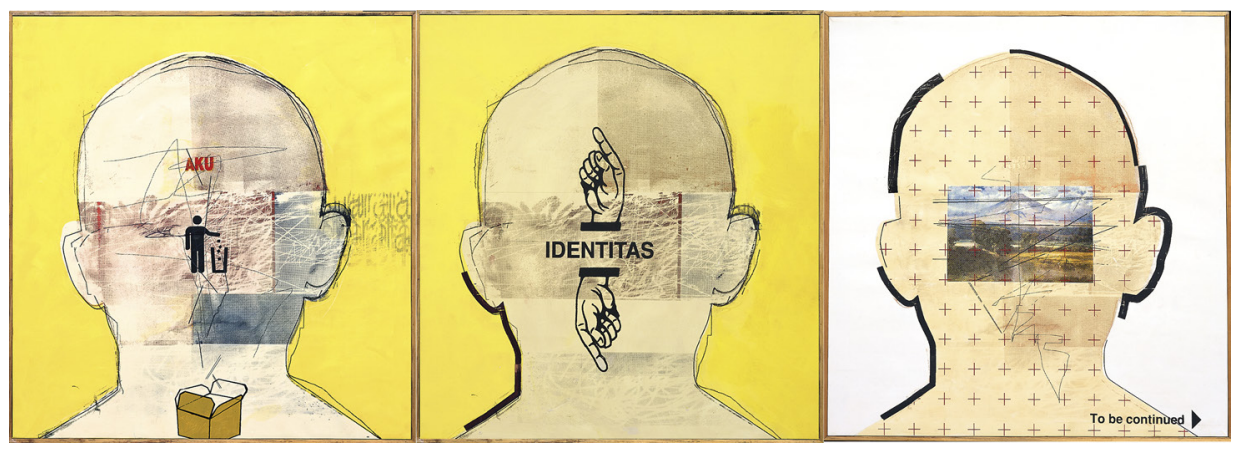

\section{FX Harsono, Identity 2003; screenprint on canvas; 3 panels, each 93.5 x $90 \mathrm{~cm}$.}

Photograph provided by the artist

Postmodernity in the international and transnational domains has forced the joining of the local to other-worlded modernism, to exogenously and hegemonically directed dissolution and reconstitution of binaries, like 'the West' and 'the East', Orientalism and Counter-Orientalism, however much these binaries and their dissolution might appear liberatory from a global position. This situation was in some ways a reinstitution of a lack of freedom, since these decomposing binaries or their oppositions, were frames which the local had to adopt in order to appear worlded to others. Many artists necessarily fought against this, but did not have the vocabulary, the economic resources, or the theoretical imperative to fully overcome them.

Two other phenomena, which can be observed in Paris and other Euramerican art capitals, such as Amsterdam and London, should be mentioned.

The first was the massive expansion of multicultural backgrounds required of artists in thematic exhibitions. These were in some cases organised by Chinese independent curators, some resident in France, such as Fei Dawei and Hou Hanru. ${ }^{33}$ In France, in particular, non-French curators intersected with a parallel universe of French curators and thinkers, such as Jean-Hubert Martin,

33 See the catalogues Art Chinois 1990 Demain pour Hier, which include the work of Cai Guo-Qiang, Yang Jiechang, Yan Peiming, Gu Wenda, Huang Yongping, Chen Zhen, Chen Qigang (curated by Fei Dawei, organised by Association Française d'Action Artistique \& Les Domaines de l'Art at Pourrières); and, Paris pour escale (2000), note 17 above. 
Jerôme Sans, and Nicolas Bourriaud, who were interested in relativising the status of Euramerican art practices and also in seeing art objects through paradigms of relationality co-created by artist and audience. Art was mobilised for exhibition that referred to global issues, such as flows of information or environment, but where, I would argue, the 'Chinese' reference was incidental. Paris/France was simply one site among others, and official reports indicated its earlier status had been lost or was in sway to unsurmountable forces in the international art world. ${ }^{34}$ The new biennales, several of which were held in Asia, were a further loop in this process of de-culturalisation of specific discursive references. But paradoxically, for the receiving Euramerican art cultures, they were a simultaneous cultural broadening of general exhibition context in which the works were shown.

In the middle of this change, only acknowledged by the presence of new exhibition spaces, such as the Palais du Tokyo, and the collection role assigned to new regional art centres in France, were the tendencies to spectacularisation evident in the creation of gargantuan art works to fill huge spaces.

A second phenomenon, which was evident by the 1990s, was that international houses of luxury consumer goods, many of which were French-owned or based in Paris, began to recognise a new trend in the way cultural references could be attached to objects, particularly high-end consumer goods, and engaged in cultural marketing through their foundations. These cemented the cultural aura and brand power of their associated houses to new, fashionable icons of crossnationality. Paris and France became a host body for the launch of cultural goods, in some ways similar to the way haute couture figured for prêt-à-porter in the clothing industry in the second half of the twentieth century. Chinese objects and artists were prominent in these changes from the early 1990s. The tendency, which has shown no sign of abating, has expanded from China to include art and artists from other Asian countries, such as Sudarshan Shetty and his House of Shades, which was made for Louis Vuitton in 2009/2010 and displayed in a galleria in Milan, or Eko Nugroho from Indonesia, whose mural installation Republic of Lost and Found was exhibited at Espace Culturel Louis Vuitton in June 2011, as part of the exhibition Trans-Figurations: Indonesian Mythologies. ${ }^{35}$

\footnotetext{
34 See Alain Quemin, L'art contemporain international: entre les institutions et le marché (le rapport disparu) (Nîmes: Éditions Jacqueline Chambon / Artprice, 2002).

35 Among prominent cases are the Fondation Cartier exhibitions of Huang Yongping in 1994 and 1997, Louis Vuitton Chinese pre-modern luxury object exhibitions 2004, the activities of Chanel in its Mobile art campaign in 2008 including the work of Yang Fudong, and Eko Nugroho's projects were also at Espace Culturel Louis Vuitton in June 2011.
} 


\section{Conclusion}

I suggested in the introduction to this essay that the task of understanding the Asian Modern is first of all to know what the artists did, to map their work and times, and then to compare them; that cohorts have the feature of viewing the 'worlding of the Asian Modern' as both an inward or exogenous process and, at the same time, an outward and endogenous one. They take art history away from seeing change as dependent on external or hegemony-down origination, and as a much more complex intermediate zone in part isolated from the very forces of modernity they also manifest.

It is a feature of the generational cohorts of artists that they represent in many cases also a periodisation. This marks simultaneously an overlapping absorption of Euramerican art techniques and institutions with their local repositioning against other and prior art discourses. These processes took place in Asia, as state units so differently and variegatedly constituted from semi-colonies (littoral China), full colonies (India and French Indo-China), settler colonies (Australia and New Zealand) and two relatively free states (Siam and Japan). It happened in cultural zones with both extensive discourses of two-dimensional art and their histories and ideas (China, Korea and Japan) as well as including those where two-dimensional representation was relatively tabooed (the courts of Sumatra and Java, the Malay States). As I proposed at the beginning of this essay, it is important now, in postcolonial times, to reconsider more carefully the ways of conceiving the distinction between exogenous and endogenous art discourses since the resulting works have become the originary works for long-term and, in most cases, almost wholly endogenous genealogies of the Asian Modern. 
This text taken from Contemporary Asian Art and Exhibitions: Connectivities and world-making, by Michelle Antoinette and Caroline Turner, published 2014 by ANU Press, The Australian National University, Canberra, Australia. 